\title{
Agrobacterium-Mediated Genetic Transformation of the Medicinal Plant Veratrum dahuricum
}

\author{
Rui Ma ${ }^{1,+}$, Zhijing Yu ${ }^{1,+}$, Qinan Cai ${ }^{1}$, Haiyun $\mathrm{Li}^{1}$, Yingshan Dong ${ }^{1, *}$, \\ Kirsi-Marja Oksman-Caldentey ${ }^{2}$ (1) and Heiko Rischer ${ }^{2, *}$ (C) \\ 1 Jilin Provincial Key Laboratory of Agricultural Biotechnology, Jilin Academy of Agricultural Sciences, \\ Changchun 130033, China; rui.ma@cjaas.com (R.M.); yuzhijing@cjaas.com (Z.Y.); caiqinan@cjaas.com (Q.C.); \\ hyli@cjaas.com (H.L.) \\ 2 VTT Technical Research Centre of Finland Ltd., P. O. Box 1000, FI-02044 VTT, Espoo, Finland; \\ Kirsi-Marja.Oksman@vtt.fi \\ * Correspondence: ysdong@cjaas.com (Y.D.); heiko.rischer@vtt.fi (H.R.); Tel.: +86-0431-8706-3008 (Y.D.); \\ +358-20-722-4461 (H.R.) \\ $+\quad$ Rui Ma and Zhijing Yu have contributed equally to this article.
}

Received: 20 December 2019; Accepted: 1 February 2020; Published: 4 February 2020

\begin{abstract}
Veratrum dahuricum L. (Liliaceae), a monocotyledonous species distributed throughout the Changbai mountains of Northeast China, is pharmaceutically important, due to the capacity to produce the anticancer drug cyclopamine. An efficient transformation system of Veratrum dahuricum mediated with Agrobacterium tumefaciens is presented. Murashige and Skoog (MS) medium containing $8 \mathrm{mg} / \mathrm{L}$ picloram was used to induce embryogenic calli from immature embryos with $56 \%$ efficiency. A. tumefaciens LBA4404 carrying the bar gene driven by the cauliflower mosaic virus $35 \mathrm{~S}$ promoter was employed for embryogenic callus inoculation. A. tumefaciens cell density OD660 $=0.8$ for inoculation, half an hour infection period, and three days of co-culture duration were found to be optimal for callus transformation. Phosphinothricin (PPT, $16 \mathrm{mg} / \mathrm{L}$ ) was used as the selectable agent, and a transformation efficiency of $15 \%$ (transgenic plants/100 infected calli) was obtained. The transgenic nature of the regenerated plants was confirmed by PCR and Southern blot analysis, and expression of the bar gene was detected by RT-PCR and Quick PAT/bar strips. The steroid alkaloids cyclopamine, jervine, and veratramine were detected in transgenic plants, in non-transformed and control plants collected from natural sites. The transformation system constitutes a prerequisite for the production of the pharmaceutically important anticancer drug cyclopamine by metabolic engineering of Veratrum.
\end{abstract}

Keywords: Veratrum dahuricum; cyclopamine; Agrobacterium tumefaciens; transformation

\section{Introduction}

Veratrum dahuricum (Liliaceae), often referred to as mountain corn, which was used as traditional Chinese medicine in the treatment of stroke, dysentery, jaundice, headache, and chronic malaria, grows in the Changbai mountains of Northeast China [1]. The genus Veratrum comprises up to 45 species of perennial herbs occurring throughout the northern temperate and Arctic regions of Europe, Asia, and North America [2]. A wide range of interesting pharmacological effects has been attributed to steroid alkaloids of Veratrum [1].

Initially, veterinarians in the USA realized that a high percentage of sheep which had consumed Veratrum californicum during early pregnancy gave birth to deformed lambs, varying from cyclopia to mildly deformed upper jaws [3]. Cyclopamine (11-deoxojervine) and jervine (Figure 1a,b) turned out to be the responsible teratogens $[4,5]$. Dedicated investigation of cyclopamine-induced teratogens showed that the compound selectively blocks the sonic hedgehog ( $\mathrm{SHh}$ ) signaling pathway. This pathway 
is crucial in human embryogenesis and tissue differentiation [6]. Subsequently, cyclopamine and its derivatives have shown promising antineoplastic activities against several cancers that arise from the disruption of the SHh pathway [7], because several genes in the pathway have been associated with these tumors. Examples include pancreatic cancer [8,9], renal cell carcinoma [10], basal cell carcinoma [11,12], medulloblastoma tumor [13], small cell lung cancer [7], and leukemia [14]. Cyclopamine and its semi-synthetic analog, IPI-926, have entered clinical trials for the treatment of several cancers, including medulloblastoma, pancreatic cancer, and leukemia $[9,14,15]$.

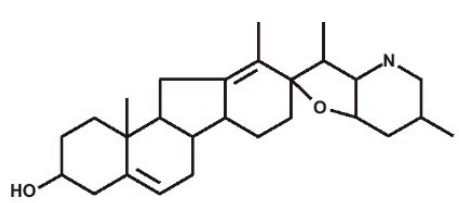

a

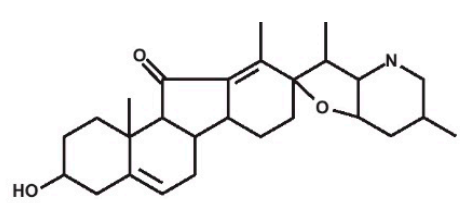

b

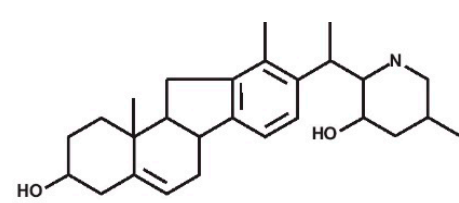

C

Figure 1. Chemical structures of cyclopamine (a), jervine (b), and veratramine (c).

The cyclopamine supply is limited. The commercial cultivation of $V$. californicum has not been achieved so far and therefore wild populations are collected for extraction. Wild plants, however, contain highly variable quantities of the alkaloid. The chemical structure of cyclopamine is complex and chemical synthesis is not economic either. The biotechnological production of the compound is therefore an attractive alternative approach. Aided by the rapid development of metabolic engineering, it can be envisioned to produce the target compound by genetically engineered plants or corresponding cell, tissue, and organ cultures [16]. In vitro culture of Veratrum has already been established [17], and several functional genes covering the early steps in the biosynthesis of cyclopamine have been characterized [18]. However, a genetic transformation system of Veratrum has not been available, preventing the biotechnological improvement of compound production by genetic engineering so far.

In this paper we report a complete genetic transformation method for $V$. dahuricum, a species producing the pharmaceutically important steroid alkaloids cyclopamine, jervine, and veratramine (Figure $1 \mathrm{a}-\mathrm{c}$ ). The transformation system comprises embryogenic callus induction, callus infection by Agrobacterium tumefaciens, transgenic callus selection, and plant regeneration. The transformation method constitutes an indispensable tool for the functional analysis of genes involved in the steroidal alkaloid biosynthesis and the improved production of the anticancer drug cyclopamine by metabolic engineering.

\section{Materials and Methods}

\subsection{Embryogenic Callus Induction}

Immature seeds were harvested from Veratrum dahuricum (Turcz.) Loes.f growing in the Changbai Mountains of Northeast China at the end of July, and wild plants were collected in April. The seeds were surface sterilized with $70 \%(v / v)$ ethanol and then sterilized by $1.6 \%(v / v)$ sodium hypochlorite supplemented with a few drops of Tween 20 for $15 \mathrm{~min}$, followed by washing three times with sterile water. Immature embryos were excised under an anatomic microscope and cultured on modified Murashige and Skoog (MS) medium [19], consisting of MS basic salts and vitamins, $146 \mathrm{mg} / \mathrm{L}$ glutamine, $200 \mathrm{mg} / \mathrm{L}$ casein hydrolysate, solidified with $3 \mathrm{~g} / \mathrm{L}$ phytagel, and supplemented with $8 \mathrm{mg} / \mathrm{L}$ picloram as growth regulator in the dark at $26^{\circ} \mathrm{C}$. Produced calli were subcultured to fresh plates at three to four weeks intervals. After three to four months of culture, the embryogenic calli were transferred to AA medium [20], supplemented with $4 \mathrm{mg} / \mathrm{L}$ of the phytohormone 2,4-D, solidified with $3 \mathrm{~g} / \mathrm{L}$ phytagel, and subcultured to fresh plates at three to four weeks intervals. 


\subsection{Transformation and Plant Regeneration}

The fast growing and fresh yellow embryogenic calli (subcultured for about 3 weeks) were used as explants for infection. Agrobacterium tumefaciens strain LBA4404 harboring a binary vector pCAMBIA3300 (Figure 2) was employed for the transformation. The vector pCAMBIA3300 contains a bar gene expression cassette which confers resistance to the herbicide phosphinothricin (PPT). The Agrobacterium was grown on LB solid medium containing $100 \mathrm{mg} / \mathrm{L}$ kanamycin, $50 \mathrm{mg} / \mathrm{L}$ rifampicin and $50 \mathrm{mg} / \mathrm{L}$ streptomycin for $2-3$ days at $28^{\circ} \mathrm{C}$. The bacterial cultures were harvested and suspended in the modified MS liquid medium with $0-100 \mu \mathrm{M}$ acetosyringone. The Agrobacterium suspensions were adjusted to different cell densities $(\mathrm{OD} 600=0.2,0.3,0.5 .0 .8,1.0,1.2,1.4)$.

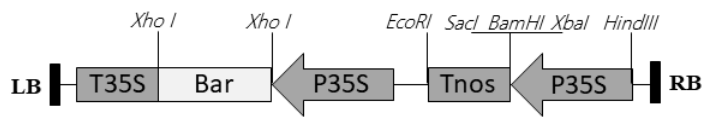

Figure 2. T-DNA region of the expression vector pCAMBIA3300-35S-bar, containing a selectable marker gene bar (phosphinothricin acetyl transferase) driven by the cauliflower mosaic virus $35 \mathrm{~S}$ promoter (P35S).

The embryogenic calli in a Petri dish were immersed in $20 \mathrm{~mL}$ of the bacterial suspension and incubated at $24{ }^{\circ} \mathrm{C}$ on a rotary shaker $(30 \mathrm{rpm})$ for $30 \mathrm{~min}$. The inoculated calli were blotted dry on sterile filter paper, then transferred to co-culture medium (modified MS medium with 0-100 $\mu \mathrm{M}$ acetosyringone, $30 \mathrm{~g} / \mathrm{L}$ sucrose and $3 \mathrm{~g} / \mathrm{L}$ phytagel and a sterilized filter paper). After co-culture for 3 days in dark at $25^{\circ} \mathrm{C}$, the co-cultured calli were washed with sterile water, blotted dry and then transferred to selection medium (AA medium with $4 \mathrm{mg} / \mathrm{L} \mathrm{2,4-D,} 30 \mathrm{~g} / \mathrm{L}$ sucrose, $3 \mathrm{~g} / \mathrm{L}$ phytagel, $250 \mathrm{mg} / \mathrm{L}$ ticarcillin, $100 \mathrm{mg} / \mathrm{L}$ cefotaxime and $16 \mathrm{mg} / \mathrm{L} \mathrm{PPT}$ ). The cultures were kept in the dark, at $25^{\circ} \mathrm{C}$ and were subcultured at 4 week intervals.

After 3-4 cycles of selection, the PPT resistant calli were transferred to solid regeneration medium R2M [21] with $3 \mathrm{mg} / \mathrm{L}$ 6-BA, $3 \mathrm{~g} / \mathrm{L}$ phytagel, $8 \mathrm{mg} / \mathrm{L}$ phosphinothricin, and cultured in light (52 $\mu \mathrm{mol} \mathrm{m} \mathrm{m} \mathrm{s}^{-1}$; cool white) at $25^{\circ} \mathrm{C}$. After $4-5$ weeks, green shoots were moved to hormone-free medium R2M in a $250 \mathrm{~mL}$ Erlenmeyer flask for root development. Finally, after another $1 \mathrm{month}$, well-developed plantlets were individually potted into peat soil and transferred to the greenhouse.

\subsection{PCR Analysis}

Total genomic DNA was isolated from leaves of the putative transgenic plantlets and non-transformed plantlets using the Plant Genomic DNA Kit (Tiangen Biotech, Beijing, China), according to the supplier extraction protocol. E. coli and Agrobacterium tumefaciens LBA4404 plasmid DNA was isolated using Qiagen Plasmid mini Kit following the instructions. The specific primers used for bar and virD gene amplification are listed in Supplementary Table S1. Expected sizes of the amplified fragments were $441 \mathrm{bp}$ and $477 \mathrm{bp}$, respectively. The PCR reaction mixture $(25 \mu \mathrm{L})$ contained $50 \mathrm{ng}$ of genomic DNA or $10 \mathrm{pg}$ plasmids, $0.5 \mu \mathrm{L}$ of $10 \mathrm{mM}$ dNTP, $2.5 \mu \mathrm{L}$ of $10 \times$ PCR buffer, $1 \mu \mathrm{L}$ each of $10 \mathrm{mM}$ forward and reverse primers, $0.2 \mu \mathrm{L}$ of $5 \mathrm{U} / \mu \mathrm{L}$ Taq enzyme (Tiangen Biotech, Beijing, China) and $18.8 \mu \mathrm{L}$ ddH2O. The PCR condition for bar gene amplification was $94{ }^{\circ} \mathrm{C}$ for $5 \mathrm{~min}, 94$ for $45 \mathrm{~s}$, $55{ }^{\circ} \mathrm{C}$ for $45 \mathrm{~s}, 72{ }^{\circ} \mathrm{C}$ for $1 \mathrm{~min}$ with 35 cycles, following $72^{\circ} \mathrm{C}$ for $10 \mathrm{~min}$. The PCR condition for virD gene amplification was $94{ }^{\circ} \mathrm{C}$ for $5 \mathrm{~min}, 94$ for $45 \mathrm{~s}, 58^{\circ} \mathrm{C}$ for $1 \mathrm{~min}, 72^{\circ} \mathrm{C}$ for $1 \mathrm{~min}$ with 35 cycles, following $72{ }^{\circ} \mathrm{C}$ for $10 \mathrm{~min}$.

\subsection{Reverse Transcription-PCR (RT-PCR) Analysis}

Total RNA was isolated from leaves of the transgenic plantlets and the control non-transformed plantlets following the protocol of Plant RNA Extract Kit (Invitrogen) and then treated with amplification grade DNaseI (Invitrogen) to remove all DNA. RNA was reverse transcribed to cDNA with a TransScript one-step gDNA Removal and cDNA synthesis SuperMix Kit (TransGen, Beijing, China). 
The first-strand cDNA was then diluted tenfold to amplify a specific $441 \mathrm{bp}$ bar fragment following the protocol mentioned before for genomic DNA amplification using the same primer pair.

\subsection{Southern Blot Analysis}

Total genomic DNA of the putative transgenic plantlets and non-transformed plantlets was extracted using a modified CTAB (cetyltrimethylammonium bromide) method [22]. Genomic DNA $(30 \mu \mathrm{g})$ was digested with EcoR I, then subjected to electrophoresis in $0.8 \%(w / v)$ agarose gels and subsequently transferred to positively charged nylon membranes (GE Amersham, Beijing, China) by capillary transfer following the manufacturer's instructions. The expression vector and non-transformed plantlet were used as positive and negative controls respectively. A DIG-labelled bar probe (the PCR product with $441 \mathrm{bp}$ amplified from plasmid as above) was produced by PCR labelling. Subsequent hybridization steps were carried out with the DIG High Prime DNA Labelling and Detection Starter Kit II (Roche, Germany). Hybridization was carried out at $42^{\circ} \mathrm{C}$ for $16 \mathrm{~h}$ and staining was performed at room temperature with NBT/BCIP as substrate (following the instruction of the DIG High Prime DNA Labelling and Detection Starter Kit I, NBT /BCIP chromogenic method).

\subsection{Bar Protein Detection}

In order to detect the bar protein expression quickly, fresh leaves of the putative transgenic and non-transformed plantlets were excised in a $1.5 \mathrm{~mL}$ Eppendorf tube. The bar protein was detected by using the Quick Stick Kit for LibertyLink (bar) (ENVIROLOGIX, Portland, Maine, USA) according to the protocol of the manufacturer.

\subsection{Extraction and Targeted HPLC Analysis}

Of the lyophilized plant material, $100 \mathrm{mg}$ were milled into powder and suspended in $4 \mathrm{~mL}$ ethanol $(80 \%$, at ratio $1: 4 w / w)$ for $1 \mathrm{~h}, 16 \mathrm{~mL}$ ethanol $(95 \%$, at ratio $1: 4 \mathrm{w} / \mathrm{w})$ was added, and the sample was extracted by agitation reflux for $2 \mathrm{~h}$ at $80^{\circ} \mathrm{C}$. Following filtration, the filtrate was collected and the sample residue was re-extracted twice with another $16 \mathrm{~mL}$ ethanol $(95 \%$, at ratio 1:8 w/w). The filtrates were combined and the solvent was evaporated to dryness. The extract was re-dissolved in $200 \mathrm{~mL}$ of methanol in an ultrasonic bath (Power $250 \mathrm{~W}$, Frequency $40 \mathrm{kHz}$ ) for $1 \mathrm{~min}$, and then filtered using a $0.22 \mu \mathrm{m}$ membrane. The filtrate was collected for HPLC analysis.

HPLC separation was performed using an Agilent 1260 Infinity system with a VWD monitor. An aliquot of $20 \mu \mathrm{L}$ of sample was loaded onto a reverse-phase C18 column (Diamonsil C18, $4.6 \times$ $250 \mathrm{~mm}, 5 \mu \mathrm{m}$ stainless steel, Diamonsil Science and Technology Company, Beijing, China) at $30^{\circ} \mathrm{C}$. The sample was eluted within $30 \mathrm{~min}$ using isocratic conditions of methanol and $0.1 \mathrm{M}$ ammonium acetate $(60: 40, v / v)$ applying a flow of $1 \mathrm{~mL} / \mathrm{min}$. UV detection was operated at a wave length of $220 \mathrm{~nm}$. Commercially available alkaloids cyclopamine, jervine, and veratramine (LC Laboratories, Woburn, Maryland, USA) were used as reference compounds.

\subsection{Statistical Analysis}

Frequencies of immature embryos producing embryogenic calli (embryogenic calli/100 explants), frequencies of growing embryogenic calli in the experiment for PPT selection effects, and frequencies of transformation (transgenic plants/100 infected calli) in the experiments for influencing parameters optimization were recorded. Completely randomized designs (CRD) were used in the experiments. Each treatment contained five replicates. Data analyses with two treatment levels were carried out by $\mathrm{t}$-test and with more than two treatment levels by the ANOVA procedure. Multi-range comparisons were performed by Fisher's Least Significant Difference (LSD) test. 


\section{Results and Discussion}

\subsection{Embryogenic Callus Induction}

In embryo cultures of monocotyledonous plants, induction of somatic embryogenesis is generally influenced by several factors including, e.g., embryo size [23,24], culture medium [25-27], and growth regulators $[24,25,28]$. For optimal results, these parameters must be empirically determined. Considering Veratrum, only conditions for V. californicum had been published [17]. In this case, embryos with 2-4 mm size cultured on modified MS medium with picloram showed the best results for embryogenic callus production [17].

We expected that similar conditions could work for $V$. dahuricum and, indeed, embryogenic calli were successfully induced from isolated immature embryos (embryo size 2-3 mm) of surface sterilized seeds (Figure 3a) on modified MS medium with $8 \mathrm{mg} / \mathrm{L}$ picloram (Figure 3b). The induction frequency of embryogenic calli (embryogenic calli/100 explants) was $56 \%(n=520)$. The embryogenic calli with a high regeneration potential were successfully proliferated by subculturing at 3-4 week intervals (Figure 3c,d). The efficiency for green plant regeneration (green plantlets/100 calli) was 95\% $(n=254$ ).
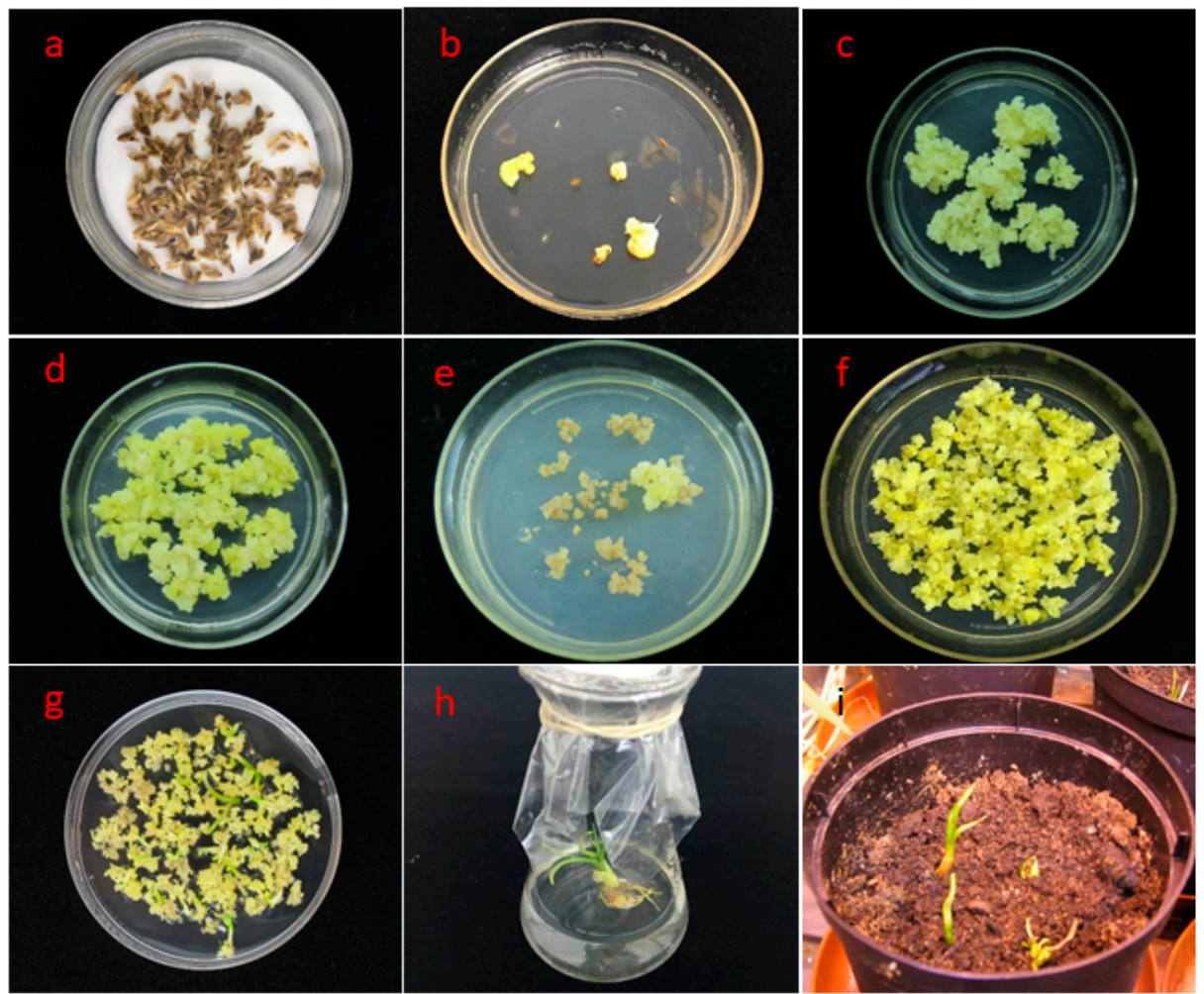

Figure 3. Genetic transformation of Veratrum dahuricum mediated with Agrobacterium tumefaciens carrying pCAMBIA3300-35S-bar expression vector. (a) Surface sterilized seeds of Veratrum dahuricum; (b) embryogenic calli induction on modified MS-medium containing $8 \mathrm{mg} / \mathrm{L}$ picloram; (c,d) proliferation of embryogenic calli in AA medium containing $4 \mathrm{mg} / \mathrm{L}$ picloram; (e) transgenic callus selection on AA medium containing $4 \mathrm{mg} / \mathrm{L} \mathrm{2,4-D} \mathrm{and} 16 \mathrm{mg} / \mathrm{L} \mathrm{PPT;} \mathrm{(f)} \mathrm{growing} \mathrm{transgenic} \mathrm{calli} \mathrm{with} \mathrm{bar} \mathrm{gene} \mathrm{on} \mathrm{AA}$ selection medium; (g) green plant regeneration on R2M medium containing $3 \mathrm{mg} / \mathrm{L}$ 6-BA; (h) rooted plantlets on hormone free medium R2M; (i) potted plantlets in peat soil.

\subsection{Determination of PPT Concentration for Transgenic Callus Selection}

PPT, together with the bar gene which confers resistance to PPT, is widely used as a selection agent in plant genetic transformation for example in crops such as maize, rice, wheat, and soybean [29-32]. Typically, concentrations in selection media vary from 2-6 ppm. 
Initial experiments were conducted to establish the suitable PPT concentration in the selection medium of $V$. dahuricum to select putative transgenic calli. Interestingly, the embryogenic calli of $V$. dahuricum displayed low sensitivity to PPT compared to the plants mentioned above. A suitable PPT concentration was $16 \mathrm{mg} / \mathrm{L}$ resulting in almost complete inhibition of callus growth within four weeks (about $5.1 \%$ surviving calli, $\mathrm{n}=690$, Figure 4 ). Hence, the concentration of $16 \mathrm{mg} / \mathrm{L}$ PPT in selection medium was used in subsequent transgenic callus selection.
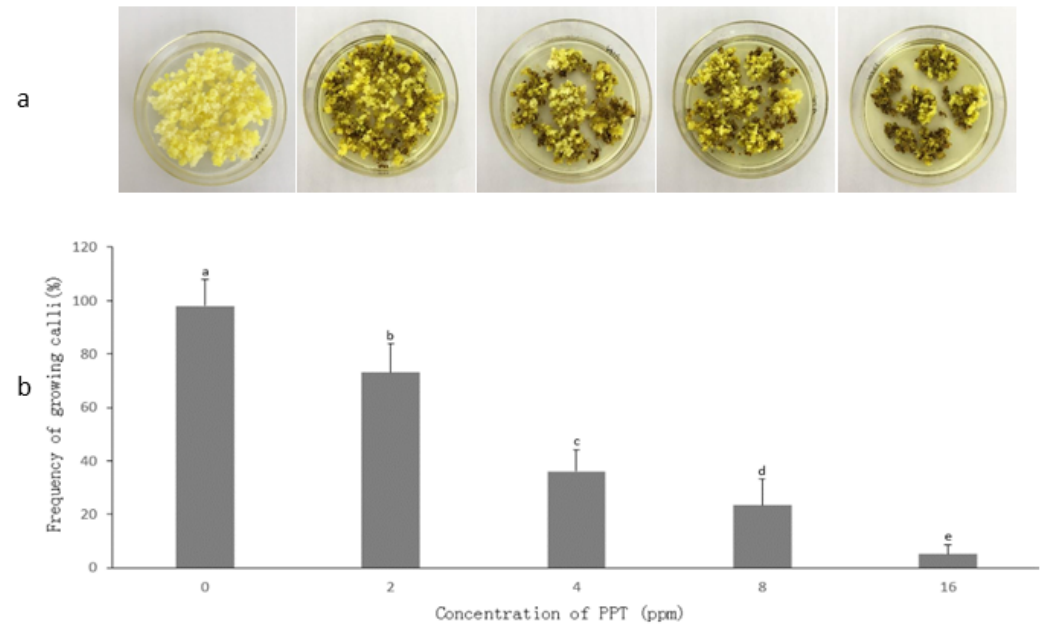

Figure 4. Selection effect of PPT concentrations on calli of Veratrum dahuricum after 4-week culture. (a) Calli on selection medium with different PPT concentrations, (b) selection efficiency of different PPT concentrations $(n=690)$. Treatments (means \pm SD) followed by a different letter are significantly different according to the LSD test $(p<0.05)$.

\subsection{Optimization of Agrobacterium Cell Density}

Cell density of Agrobacterium is another important factor influencing genetic transformation. In previous studies for plant transformation, such as in rice [30], maize [33], soybean [32], wheat [34], clove basil [35], and jute [36], optimum cell densities varied from $\mathrm{OD}=0.1-\mathrm{OD}=1.0$ depending on Agrobacterium strains, plant species, and explants.

For V. dahuricum an Agrobacterium density of OD600 $<0.5$ was ineffective for the transformation, whereas OD600 $>1.0$ led to the death of the calli, due to overgrowth of bacteria. The highest transformation frequency of $12 \%(n=933)$ was achieved with a cell density of about OD600 $=0.8$ (Figure 5a).

\subsection{Effect of Acetosyringone on Transformation Efficiency}

Acetosyringone, a phenolic compound exuded from plant wounds, has been used in Agrobacterium-mediated transformation during infection to increase transformation frequency $[33,37,38]$. Acetosyringone concentrations typically range from $20-200 \mu \mathrm{M}$, depending on the plant species $[32,33,37,38]$.

In the case of $V$. dahuricum, the transformation efficiency was significantly increased by the addition of acetosyringone to the infection and co-culture medium. Different concentrations of acetosyringone in the range of $0-100 \mu \mathrm{M}$ were added to the co-culture medium at the infection time. The highest transformation efficiency $(14 \%, \mathrm{n}=500)$ was achieved at a concentration of $20 \mu \mathrm{M}$ acetosyringone (Figure 5b). 

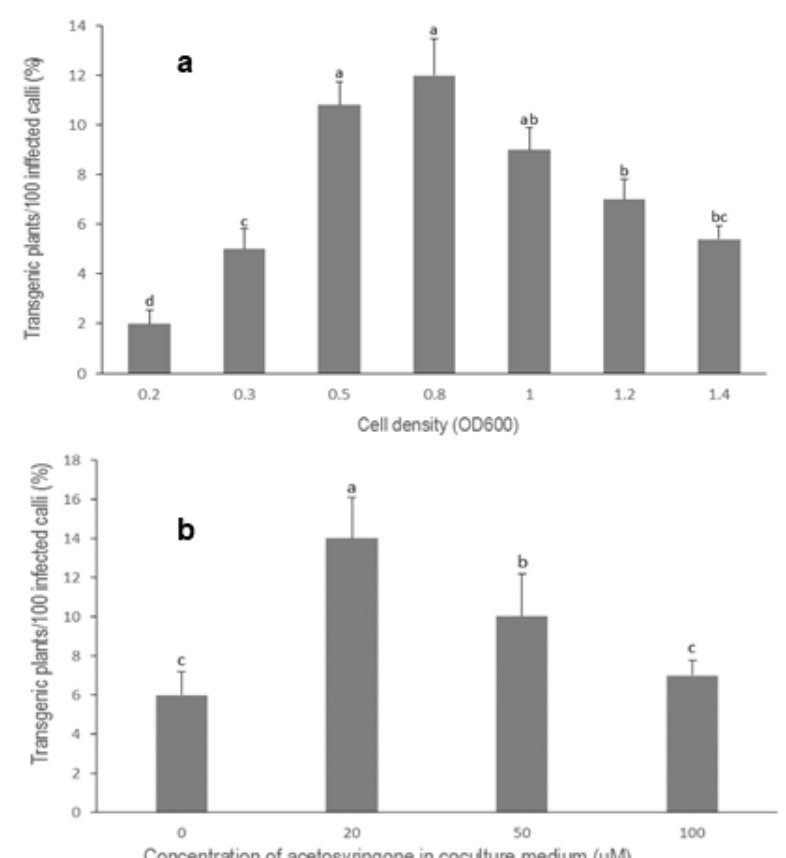

Concentration of acetosyringone in coculture medium $(\mu \mathrm{M})$

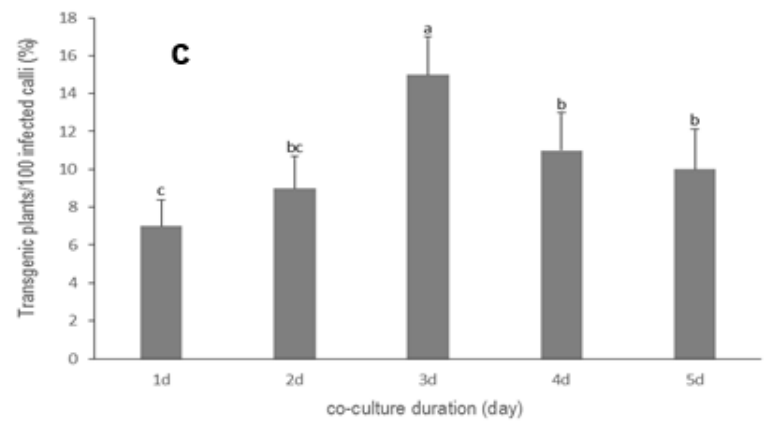

Figure 5. Factors influencing transformation efficiencies of Veratrum dahuricum. Treatments (means \pm SD) followed by a different letter are significantly different according to the LSD test $(p<0.05)$. (a) Influence of Agrobacterium cell density on transformation efficiency ( $\mathrm{n}=933)$, (b) effects of acetosyringone on transformation efficiency $(n=500)$, (c) influence of co-culture duration on transformation efficiency $(\mathrm{n}=633)$.

\subsection{Influence of Co-Culture Duration on Transformation Efficiency}

In the Agrobacterium-mediated genetic transformation of plants, transfer of T-DNA from Agrobacterium to the plant is a time-dependent process and the duration varies widely from a few hours to a few days, depending on the Agrobacterium strain and the plant species [39]. Co-culture duration is therefore one of the main factors affecting transformation efficacy. In many plant transformation studies, e.g., in maize [40], rice [30], wheat [34], soybean [41], okra [39], and clove basil [35], suitable co-culture duration varied from two to five days.

In our studies, co-culture duration significantly influenced the transformation efficiency of $V$. dahuricum. Within the period of five days, there was a clear optimum at day three (Figure 5c). Approximately $15 \%$ transgenic plants were recovered $(n=633)$. A further increase of co-culture duration led to lower transformation frequency, due to visible overgrowth of Agrobacterium.

\subsection{Transgenic Callus Selection and Transformed Plant Regeneration}

Transgenic callus selection and maintenance of embryogenic capacity and regeneration potential have been a critical problem to overcome in the establishment of efficient transformation systems [23]. 
In our study with $V$. dahuricum, infected calli were moved to selection medium AA after co-culture. Following three to four cycles of selection, PPT resistant calli were obtained (Figure 3e,f) and plated on solid regeneration medium R2M. Already after another four to five weeks, green shoots regenerated and these were transferred to hormone-free R2M medium in $250 \mathrm{~mL}$ Erlenmeyer flasks for root development (Figure 3g). Fully developed plantlets (Figure 3h) were then potted in peat soil and successfully weaned in the greenhouse (Figure $3 i$ ).

\subsection{Molecular Analysis of Putative Transgenic Plants}

Putative transformed plants were evaluated by PCR and Southern blot. The PCR amplified DNA fragment of the bar gene from transgenic plants was $441 \mathrm{bp}$ which was in accordance with the expected amplification size. DNA from a non-transformed control plant did not show any amplified fragment (Figure 6a). The transgenic nature of the plants was further confirmed by Southern blot hybridization. DNA from transgenic plants showed hybridization fragments with one (Figure $6 \mathrm{~b}$ ) to three copies (Supplementary Figure S2), whereas DNA from non-transformed control plants did not generate any hybridization band (Figure $6 \mathrm{~b}$ ). These results indicated that the bar gene was successfully integrated into the genome of $V$. dahuricum. Three selected transgenic plants with a single copy of the bar gene showed the expected $441 \mathrm{bp}$ fragment amplified by qualitative RT-PCR which demonstrated that the bar gene was indeed transcribed (Figure 6c). The Bar protein was expressed in the transgenic $V$. dahuricum plants, while a non-transformed control plant did not show Bar protein test line (Figure 6d). Plants were free of persisting Agrobacterium, as shown by virD PCR (Supplementary Figure S3).
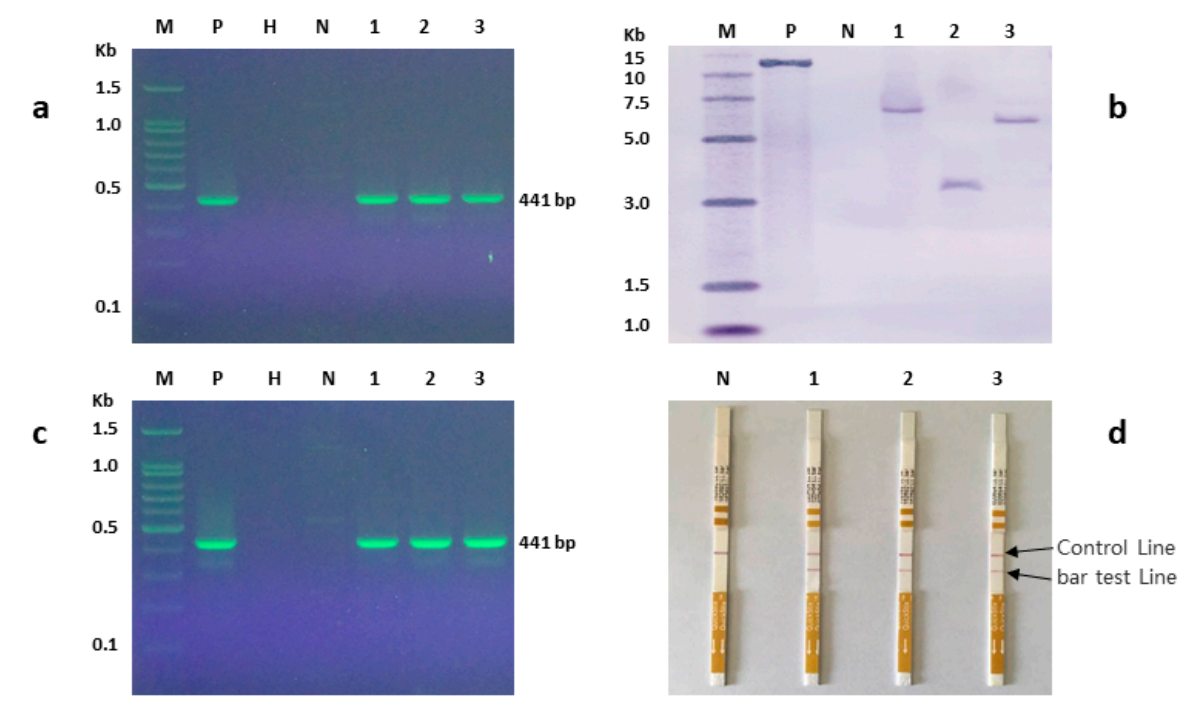

Figure 6. Molecular analysis of Veratrum dahuricum regarding bar (phosphinothricin acetyl transferase) gene. M: DNA molecular weight marker, P: positive control of plasmid pCAMBIA3300-35S-bar, H: negative water control, N: non-transformed control plant, 1-3: transgenic plants (a) PCR analysis showing the expected $441 \mathrm{bp}$ band in the positive control and transgenic plants 1-3; (b) Southern blot analysis showing the single hybridized band in the positive control and transgenic plants $1-3$. Plant genomic DNA and plasmid were digested with EcoR I and hybridized with digoxigenin (DIG) labelled bar probe. (c) Expression analysis of bar gene in transgenic plants by RT-PCR using bar gene primers. The expected $441 \mathrm{bp}$ band is visible in the positive control and transgenic plants 1-3; (d) Bar protein expression analysis by ENVIROLOGIX quick stick kit for LibertyLink (bar). Transgenic plants 1-3 showing BAR.

\subsection{Cyclopamine Content of Transgenic Plants}

The steroid alkaloids cyclopamine, jervine, and veratramine were extracted from transgenic plants, non-transformed control plants, and wild collected plants. The contents of the alkaloids in the plants 
were determined by targeted HPLC-UV. All three alkaloids were detected in the examined plants but significant quantitative differences $(p>0.05)$ were not found (Table 1, Supplementary Figure S4).

Table 1. Contents of steroid alkaloids in different plant sources.

\begin{tabular}{ccccc}
\hline \multirow{2}{*}{ Plant Source } & \multicolumn{3}{c}{ Contents of Steroid Alkaloids (mg/100 g dw) } \\
\cline { 2 - 5 } & Cyclopamine & Jervine & Veratramine & Total \\
\hline Transgenic plant & $3.89 \mathrm{a}$ & $12.79 \mathrm{a}$ & $26.54 \mathrm{a}$ & $43.22 \mathrm{a}$ \\
Non-transformed control plant & $3.83 \mathrm{a}$ & $13.56 \mathrm{a}$ & $25.04 \mathrm{a}$ & $42.43 \mathrm{a}$ \\
Wild collected control plant & $4.24 \mathrm{a}$ & $11.43 \mathrm{a}$ & $23.36 \mathrm{a}$ & $39.03 \mathrm{a}$ \\
\hline
\end{tabular}

Means $(n=6)$ followed by the same letters are not significantly different according to the LSD test $(p<0.05)$.

All three alkaloids, cyclopamine, jervine, and veratramine have earlier been found in V. californicum. Biosynthetically cyclopamine derives from cholesterol, while both veratramine and jervine are subsequent derivatives of cyclopamine [42]. The contents of cyclopamine in wild collected Veratrum plants vary considerably from 39-800 mg/100 g dw depending on the location and growth stage [43,44]. In the present study contents of cyclopamine in transgenic and non-transformed and wild collected control plants were rather low: 3.89, 3.83, and $4.24 \mathrm{mg} / 100 \mathrm{~g} \mathrm{dw}$, respectively. Although with a low likelihood, T-DNA insertional mutagenesis can knock out biosynthetic genes [45] and even adjacent integration may affect expression levels [46]. The transformation of $V$. dahuricum with only a selection marker did not alter cyclopamine and total alkaloid contents and therefore an influence of the integrated gene on biosynthetic genes is not apparent.

\section{Conclusions}

The establishment of transformation protocols is still a largely empiric, yet indispensable exercise in order to be able to metabolically engineer non-model plant species capable of producing interesting secondary metabolites. Among the monocotyledonous Veratrum species, V. californicum and V. dahuricum contain pharmaceutically important steroid alkaloids. While basic plant regeneration methods exist for $V$. californicum, this study presents for the first time an efficient Agrobacterium-mediated genetic transformation system for Veratrum. A number of relevant factors, such as the size of explant, concentration of the selection marker, Agrobacterium cell density, acetosyringone concentration, and co-culture duration were optimized to achieve regenerated transgenic plants that were subsequently successfully weaned in the greenhouse. Transgenic and control plants contained similar amounts of the target molecules, confirming that transformation with a marker gene does not disrupt the capacity to produce these compounds. Further work will focus on the introduction of biosynthetic pathway genes that aim at modulating steroid alkaloid accumulation.

Supplementary Materials: The following is available online at http://www.mdpi.com/2223-7747/9/2/191/s1, Table S1: Primers for PCR and RT-PCR; Figure S2: Southern blot analysis showing 1-3 hybridized bands; Figure S3: PCR detection of virD; Figure S4: HPLC analysis of steroid alkaloids cyclopamine, jervine, and veratramine in the transgenic plant, non-transformed control plant, and wild collected plant of Veratrum dahuricum at wavelength $220 \mathrm{~nm}$.

Author Contributions: Conceptualization, Y.D., K.-M.O.-C. and H.R.; data curation, R.M., Z.Y., Q.C., and H.L.; investigation, R.M., Z.Y., Q.C., and H.L.; methodology, R.M., Z.Y., Q.C., and H.L.; resources, Y.D.; supervision, Y.D. and H.R.; writing-original draft, R.M. and Z.Y.; writing—review and editing, Y.D., K.-M.O.-C., and H.R. All authors have read and agreed to the published version of the manuscript.

Funding: This research was funded by the Jilin Provincial Agricultural Science \& Technology Innovation Project CXGC2017ZY029.

Acknowledgments: The authors thank Lu Yunlong for analytical support and Zhang Xuemei for tissue culture work and technical assistance.

Conflicts of Interest: The authors declare no conflict of interest. 


\section{References}

1. Yang, Z.J.; Wen, F. Introduction for the pharmacologic action of Veratrum. Chin. Pract. Med. 2016, 20, $282-283$.

2. Zomlefer, W.B.; Whitten, W.M.; Williams, N.H.; Judd, W.S. An overview of Veratrum s.l. (Liliales: Melanthiaceae) and an infrageneric phylogeny based on its sequence data. Syst. Bot. 2003, 28, 250-269.

3. Keeler, R.F.; Binns, W. Teratogenic compounds of Veratrum californicum (Durand): II. Production of ovine fetal cyclopia by fractions and alkaloid preparations. Can. J. Biochem. 1966, 44, 829-838. [CrossRef] [PubMed]

4. Keeler, R.F. Teratogenic compounds in Veratrum californicum (Durand) IX. Structure-activity relation. Teratology 1970, 3, 169-173. [CrossRef]

5. Keeler, R.F. Teratogenic compounds of Veratrum californicum (Durand): X. Cyclopia in rabbits produced by cyclopamine. Teratology 1970, 3, 175-180. [CrossRef]

6. Taipale, J.; Beachy, P.A. The Hedgehog and Wnt signalling pathways in cancer. Nature 2001, 411, 349-354. [CrossRef]

7. Watkins, D.N.; Berman, D.M.; Burkholder, S.G.; Wang, B.; Beachy, P.A.; Baylin, S.B. Hedgehog signalling within airway epithelial progenitors and in small-cell lung cancer. Nature 2003, 422, 313-317. [CrossRef]

8. Bahra, M.; Kamphues, C.; Boas-Knoop, S.; Lippert, S.; Esendik, U.; Schüller, U.; Hartmann, W.; Waha, A.; Neuhaus, P.; Heppner, F. Combination of hedgehog signaling blockage and chemotherapy leads to tumor reduction in pancreatic adenocarcinomas. Pancreas 2012, 41, 222-229. [CrossRef]

9. Olive, K.P.; Jacobetz, M.A.; Davidson, C.J.; Gopinathan, A.; McIntyre, D.; Honess, D.; Madhu, B.; Goldgraben, M.A.; Caldwell, M.E.; Allard, D.; et al. Inhibition of Hedgehog signaling enhances delivery of chemotherapy in a mouse model of pancreatic cancer. Science 2009, 324, 1457-1461. [CrossRef]

10. Behnsawy, H.M.; Shigemura, K.; Meligy, F.Y.; Yamamichi, F.; Yamashita, M.; Haung, W.C.; Li, X.; Miyake, H.; Tanaka, K.; Kawabata, M.; et al. Possible role of sonic hedgehog and epithelial-mesenchymal transition in renal cell cancer progression. Korean J. Urol. 2013, 54, 547-554. [CrossRef]

11. Gailani, M.R.; Stahle-Backdahl, M.; Leffell, D.J.; Glynn, M.; Zaphiropoulos, P.G.; Pressman, C.; Unden, A.B.; Dean, M.; Brash, D.E.; Bale, A.E.; et al. The role of the human homologue of Drosophila patched in sporadic basal cell carcinomas. Nat. Genet. 1996, 14, 78-81. [CrossRef] [PubMed]

12. Taipale, J.; Chen, J.K.; Cooper, M.K.; Wang, B.; Mann, R.K.; Milenkovic, L.; Scott, M.P.; Beachy, P.A. Effects of oncogenic mutations in Smoothened and Patched can be reversed by cyclopamine. Nature 2000, 406, 1005-1009. [CrossRef] [PubMed]

13. Berman, D.M.; Karhadkar, S.S.; Hallahan, A.R.; Pritchard, J.I.; Eberhart, C.G.; Watkins, D.N.; Chen, J.K.; Cooper, M.K.; Taipale, J.; Olson, J.M.; et al. Medulloblastoma growth inhibition by hedgehog pathway blockade. Science 2002, 297, 1559-1561. [CrossRef] [PubMed]

14. Lin, T.L.; Wang, Q.H.; Brown, P.; Peacock, C.; Merchant, A.A.; Brennan, S.; Jones, E.; Mcgovern, K.; Watkins, D.N.; Sakamoto, K.M. Self-renewal of acute lymphocytic leukemia cells is limited by the hedgehog pathway inhibitors cyclopamine and IPI-926. PLOS ONE 2010, 5, e15262. [CrossRef]

15. Tremblay, M.R.; Nesler, M.; Weatherhead, R.; Castro, A.C. Recent patents for Hedgehog pathway inhibitors for the treatment of malignancy. Expert Opin. Ther. Pat. 2009, 19, 1039-1056. [CrossRef]

16. Oksman-Caldentey, K.M.; Inze, D. Plant cell factories in the post-genomic era: New ways to produce designer secondary metabolites. Trends Plant Sci. 2004, 9, 433-440. [CrossRef]

17. Ma, R.; Ritala, A.; Oksman-Caldentey, K.M.; Rischer, H. Development of in vitro techniques for the important medicinal plant Veratrum californicum. Planta Med. 2006, 72, 1142-1148. [CrossRef]

18. Augustin, M.M.; Ruzicka, D.R.; Shukla, A.K.; Augustin, J.M.; Starks, C.M.; O’Neil-Johnson, M.; McKain, M.R.; Evans, B.S.; Barrett, M.D.; Smithson, A.; et al. Elucidating steroid alkaloid biosynthesis in Veratrum californicum: Production of verazine in Sf9 cells. Plant J. 2015, 82, 991-1003. [CrossRef]

19. Murashige, T.; Skoog, F. A revised medium for rapid growth and bioassays with tobacco tissue culture. Physiol. Plant. 1962, 15, 473-497. [CrossRef]

20. Müller, A.J.; Grafe, R. Isolation and characterization of cell lines of Nicotiana tabacum lacking nitrate reductase. Mol. Gen. Genet. 1978, 161, 67-76. [CrossRef]

21. Wang, X.; Han, H. The effect of Potato II medium for triticale anther culture. Plant Sci. Lett. 1984, 36, $237-239$.

22. Telzur, N.; Abbo, S.; Myslabodski, D.; Mizrahi, Y. Modified CTAB procedure for DNA isolation from epiphytic cacti of the genera Hylocereus and Selenicereus (Cactaceae). Plant Mol. Biol. Report. 1999, 17, 249-254. [CrossRef] 
23. Lührs, R.; Lörz, H. Plant regeneration in vitro from embryogenic cultures of spring- and winter-type barley (Hordeum vulgare L.) varieties. Theor. Appl. Genet. 1987, 75, 16-25. [CrossRef]

24. Ma, R.; Pulli, S. Factors influencing somatic embryogenesis and regeneration ability in somatic tissue culture of spring and winter rye. Agric. Food Sci. 2004, 13, 363-377. [CrossRef]

25. Armstrong, C.L.; Green, C.E. Establishment and maintenance of friable, embryogenic maize callus and the involvement of L-proline. Planta 1985, 164, 207-214. [CrossRef]

26. Nhut, D.T. Micropropagation of lily (Lilium longiflorum) via in vitro stem node and pseudo-bulblet culture. Plant Cell Rep. 1998, 17, 913-916. [CrossRef]

27. Chaudhuri, D.; Sen, S. In vitro response of Scilla siberica. Sci. Hortic. 2002, 95, 51-62. [CrossRef]

28. Mori, S.; Adachi, Y.; Horimoto, S.; Suzuki, S.; Nakano, M. Callus formation and plant regeneration in various Lilium species and cultivars. In Vitro Cell. Dev. Biol. Plant 2005, 41, 783-788. [CrossRef]

29. Frame, B.R.; Shou, H.; Chikwamba, R.K.; Zhang, Z.; Xiang, C.; Fonger, T.M.; Pegg, S.E.K.; Li, B.; Dan, S.N.; Pei, D. Agrobacterium tumefaciens-mediated transformation of maize embryos using a standard binary vector system. Plant Physiol. 2002, 129, 13-22. [CrossRef]

30. Toki, S. Rapid and efficient Agrobacterium-mediated transformation in rice. Plant Mol. Biol. Report. 1997, 15. [CrossRef]

31. Hu, T.; Metz, S.; Chay, C.; Zhou, H.P.; Biest, N.; Chen, G.; Cheng, M.; Feng, X.; Radionenko, M.; Lu, F.; et al. Agrobacterium-mediated large-scale transformation of wheat (Triticum aestivum L.) using glyphosate selection. Plant Cell Rep. 2003, 21, 1010-1019. [CrossRef]

32. Paz, M.M.; Martinez, J.C.; Kalvig, A.B.; Fonger, T.M.; Wang, K. Improved cotyledonary node method using an alternative explant derived from mature seed for efficient Agrobacterium-mediated soybean transformation. Plant Cell Rep. 2006, 25, 206-213. [CrossRef]

33. Zhao, Z.Y.; Gu, W.; Cai, T.; Tagliani, L.; Hondred, D.; Bond, D.; Schroeder, S.; Rudert, M.; Pierce, D. High throughput genetic transformation mediated by Agrobacterium tumefaciens in maize. Mol. Breed. 2002, 8, 323-333. [CrossRef]

34. Kumar, R.; Mamrutha, H.M.; Kaur, A.; Venkatesh, K.; Sharma, D.; Singh, G.P. Optimization of Agrobacterium-mediated transformation in spring bread wheat using mature and immature embryos. Mol. Biol. Rep. 2019, 46, 1845-1853. [CrossRef]

35. Khan, S.; Fahim, N.; Singh, P.; Rahman, L.U. Agrobacterium tumefaciens mediated genetic transformation of Ocimum gratissimum: A medicinally important crop. Ind. Crops Prod. 2015, 71, 138-146. [CrossRef]

36. Saha, P.; Datta, K.; Majumder, S.; Sarkar, C.; China, S.P.; Sarkar, S.N.; Sarkar, D.; Datta, S.K. Agrobacterium mediated genetic transformation of commercial jute cultivar Corchorus capsulariscv. JRC 321 using shoot tip explants. Plant Cell Tissue Organ Cult. 2014, 118, 313-326. [CrossRef]

37. Sheikholeslam, S.N.; Weeks, D.P. Acetosyringone promotes high efficiency transformation of Arabidopsis thaliana explants by Agrobacterium tumefaciens. Plant Mol. Biol. 1987, 8, 291-298. [CrossRef]

38. Mishra, S.; Sangwan, R.S.; Bansal, S.; Sangwan, N.S. Efficient genetic transformation of Withania coagulans (Stocks) Dunal mediated by Agrobacterium tumefaciens from leaf explants of in vitro multiple shoot culture. Protoplasma 2013, 250, 451-458. [CrossRef]

39. Markandan, M.; Subramanyam, K.; Ishwarya, R.; Elayaraja, D.; Ganapathi, A. Assessment of factors influencing the tissue culture-independent Agrobacterium-mediated in planta genetic transformation of okra [Abelmoschus esculentus (L.) Moench]. Plant Cell Tissue Organ Cult. 2015, 123, 309-320.

40. Horn, M.E.; Harkey, R.L.; Vinas, A.K.; Drees, C.F.; Barker, D.K.; Lane, J.R. Use of Hi II-Elite inbred hybrids in agrobacterium-based transformation of maize. In Vitro Cell. Dev. Biol. Plant 2006, 42, 359-366. [CrossRef]

41. Yang, X.; Yu, X.; Zhou, Z.; Ma, W.; Tang, G. A high-efficiency Agrobacterium tumefaciens mediated transformation system using cotyledonary node as explants in soybean (Glycine max L.). Acta Physiol. Plant. 2016, 38, 60. [CrossRef]

42. Kaneko, K.; Mitsuhashi, H.; Hirayama, K.; Ohmori, S. 11-Deoxojervine as a precursor for jervine biosynthesis in Veratrum grandiflorum. Phytochemistry 1970, 9, 2497-2501. [CrossRef]

43. Turner, M.W.; Cruz, R.; Mattos, J.; Baughman, N.; Elwell, J.; Fothergill, J.; Nielsen, A.; Brookhouse, J.; Bartlett, A.; Malek, P.; et al. Cyclopamine bioactivity by extraction method from Veratrum californicum. Bioorg. Med. Chem. 2016, 24, 3752-3757. [CrossRef]

44. Keeler, R.F.; Binns, W. Teratogenic compounds of Veratrum californicum as a function of plant part, stage, and site of growth. Phytochemistry 1971, 10, 1765-1769. [CrossRef] 
45. Krysan, P.J.; Young, J.C.; Sussman, M.R. T-DNA as an Insertional Mutagen in Arabidopsis. Plant Cell. 1999, 11, 2283-2290. [CrossRef]

46. Tamura, K.; Kawabayashi, T.; Shikanai, T.; Hara-Nishimura, I. Decreased expression of a gene caused by a T-DNA insertion in an adjacent gene in Arabidopsis. PLoS ONE 2016, 11, e0147911. [CrossRef]

(C) 2020 by the authors. Licensee MDPI, Basel, Switzerland. This article is an open access article distributed under the terms and conditions of the Creative Commons Attribution (CC BY) license (http://creativecommons.org/licenses/by/4.0/). 